\title{
Leksykon socjologii prawa, red. A. Kociołek-Pęksa, M. Stępień, C. H. Beck, Warszawa 2013, 465 stron
}

W polskim obiegu naukowym funkcjonuje wiele leksykonów. Od dotyczących typowej dogmatyki prawa (np. leksykony prawa karnego, morskiego, spółek handlowych etc.), poprzez pozycje biograficzne jak mający już trzy wydania Leksykon myślicieli politycznych i prawnych ${ }^{1}$, po leksykony etyki i retoryki prawniczej. Można pokusić się o stwierdzenie, że prawie każda z dziedzin prawa doczekała się już wydania „swojej” książki objaśniającej podstawowe zagadnienia z nią związane. Każda poza socjologią prawa. Dopiero w poprzednim roku pojawił się Leksykon socjologii prawa pod redakcją dr Anny Kociołek-Pęksy i dr. Mateusza Stępnia. Pozycja ważna, potrzebna i na pewno bardzo ciekawa. Choćby z punktu widzenia, że sama socjologia prawa mimo wspaniałych tradycji (L. Petrażycki) wciąż jako dziedzina nie jest w Polsce traktowana na równi z innymi obszarami badań nad prawem. Często można usłyszeć wręcz, że jedyne, co ma z prawem wspólnego, to człon w nazwie.

Redaktorzy, jak sami podkreślili we wstępie, napotkali problem obfitości zagadnień, którymi zajmuje się socjologia prawa. Dlatego poza klasycznymi, typowymi dla tej dziedziny hasłami, w książce znalazła się też problematyka, która dopiero czeka na pełne opracowanie przez socjologów prawa. Dzięki temu zabiegowi twórcom Leksykonu socjologii prawa udało się ukazać rozległość dziedziny prawa, którą się zajmują. Nie bez znaczenia pozostaje też fakt, że autorami haseł w leksykonie są nie tylko sami socjologowie prawa, ale także filozofowie i teoretycy prawa, historycy prawa i po prostu socjologowie ${ }^{2}$. Taki dobór współpracowników udowadnia, że poszczególne dyscypliny nauki wcale nie są zamkniętymi twierdzami, które się nie przenikają, a z kolei prawnicy nie są (wbrew obiegowej opinii) grupą naukowców oderwaną od nauk humanistycznych.

Należy podkreślić, że właśnie jednym z największych atutów Leksykonu socjologii prawa jest, wspomniana już, jego interdyscyplinarność i wyjście poza klasyczne ramy tematyczne. Dlatego poza omówieniem takich haseł jak: aksjologia, anomia, durkheimowska socjologia prawa czy weberowska socjologia prawa, możemy odnaleźć także zagadnienia dotyczące: chińskiej i islamskiej kultury prawnej, globalizacji prawa, czy nawet omówienie relacji między prawem a magią. Kolejnym atutem publikacji jest jej układ. Twórcy Leksykonu

\footnotetext{
Leksykon myślicieli politycznych i prawnych, red. E. Kundera, M. Maciejewski, Warszawa 2009.

2 Leksykon socjologii prawa, red. A. Kociołek-Pęksa, M. Stępień, Warszawa 2013, s. VII.
} 
socjologii prawa przyjęli najlepszy w swej prostocie układ haseł - alfabetyczny. Dzięki temu odbiorca leksykonu skupia się na jego treści, a nie, jak to bywa w przypadku innych tego typu publikacji, nad rozważaniami, czy Leon Petrażycki powinien być umieszczony między teoretykami prawa, filozofami czy myślicielami politycznymi.

Podsumowując, należy jeszcze raz podkreślić, że powstanie tej pozycji było pewnego rodzaju koniecznością i pomogło w zaznaczeniu, że socjologia prawa w Polsce istniała, istnieje i ma całkiem ciekawe perspektywy rozwojowe. Leksykon socjologii prawa utwierdza nas też $\mathrm{w}$ przekonaniu, że socjologowie prawa starają się nadążyć za zmieniającą się rzeczywistością, że nawet mimo wykształcenia prawniczego nie są oderwani od socjologii, filozofii, historii. Leksykon jest pozycją uniwersalną. Powinni sięgnąć po niego zarówno prawnicy, jak i socjologowie. Zwłaszcza że w procesie kształcenia socjologów już na zajęciach ze Wstępu do socjologii sięga się po P. Bergera i jego Zaproszenie do socjologii. Pojawia się tam słynny przykład ekonomisty, prawnika i socjologa. Być może właśnie ten leksykon i kolejne pozycje, do pisania których zostaną zaproszeni nie tylko socjologowie prawa, uświadomi niektórym, że prawnik nie porusza się tylko w granicach norm, a ekonomista w granicach praw rynku. Kończąc już swój wywód, chciałbym pogratulować autorom pomysłu i z niecierpliwością oczekuję na kolejne wydania Leksykonu socjologii prawa.

Filip Cyuńczyk 